\title{
PEMANFAATAN ABU SEKAM PADI 10\% DAN LIMBAH KACA SEBAGAI BAHAN SUBSTITUSI PADA CAMPURAN BETON MUTU fc' 25 MPA
}

\author{
Ridhwan Muhammad Iqbal ${ }^{1}$, Gati Annisa Hayu ${ }^{2}$ \\ ${ }^{12)}$ Jurusan Teknik Sipil S-1, Universitas Pertamina \\ Email: ridhwanmuhammadiqbal@gmail.com
}

\begin{abstract}
This study discusses the use of waste powder from a mixture of glass bottle colors (clear glass, amber glass, and green glass) as materials for fine aggregates and rice husk ash as a place for cement in the concrete mixture. The research was carried out by making a concrete mix design plan fc' $25 \mathrm{MPa}$ and developed on four variations of the mixture with the amount of glass waste $0 \%, 10 \%, 20 \%$, and $30 \%$ with the use of $10 \%$ rice husk ash. The purpose of this research is to see the effect of substitution materials on compressive strength and concrete including workability, repeat patterns, and adhesion of concrete aggregates. The compressive strength test was carried out at the age of 7, 14, and 28 days and visual observation of the retrieval pattern and aggregate attachment was carried out at the age of 28 days. The test object used in this study is a cylinder with a diameter of $15 \mathrm{~cm}$ and a height of $30 \mathrm{~cm}$ as many as 45 samples. From the results of the compressive strength test, the optimum value of concrete that occurs in a mixture of glass powder is $20 \%$ and rice husk ash is $10 \%$, but the resulting value is still below normal concrete. The use of substitution materials also affects the value of the workability of concrete and from visual observation of the pattern of uptake and adhesion of aggregates to concrete which tends to occur in bonds between concrete aggregates.
\end{abstract}

Keywords: Glass waste, Rice husk ash, Compressive strength.

\begin{abstract}
ABSTRAK
Penelitian ini membahas mengenai penggunaan serbuk limbah kaca dari campuran warna botol kaca (kaca bening, kaca coklat, dan kaca hijau) sebagai bahan pengganti agregat halus dan abu sekam padi sebagai bahan pengganti semen pada campuran beton. Penelitian dilakukan dengan membuat mix design beton rencana fc'25 MPa dan dikembangkan pada empat variasi campuran dengan jumlah serbuk limbah kaca $0 \%, 10 \%$, 20\%, dan 30\% dengan penggunaan abu sekam padi $10 \%$. Tujuan yang dilakukan pada penelitian ini adalah untuk mengetahui pengaruh bahan substitusi terhadap kuat tekan dan karakteristik beton yang meliputi workability, pola retak, dan lekatan agregat beton. Pengujian kuat tekan dilakukan pada umur 7, 14, dan 28 hari serta pengamatan visual terhadap pola retak dan lekatan agregat dilakukan pada umur 28 hari. Benda uji yang digunakan pada penelitian ini adalah silinder dengan diameter $15 \mathrm{~cm}$ dan tinggi $30 \mathrm{~cm}$ sebanyak 45 sampel. Dari hasil pengujian kuat tekan, nilai optimum beton variasi terjadi pada campuran serbuk kaca $20 \%$ dan abu sekam padi $10 \%$, namun nilai yang dihasilkan masih dibawah beton normal. Penggunaan bahan substitusi juga mempengaruhi terhadap nilai workability beton dan dari pengamatan visual terhadap pola retak dan lekatan agregat pada beton cenderung titik terlemah terjadi pada ikatan antar agregat beton.
\end{abstract}

Kata kunci: Limbah kaca, Abu sekam padi, Kuat tekan.

\section{PENDAHULUAN}

Pembangunan infrastruktur di Indonesia pada saat ini berkembang cukup pesat yang dibuktikan dengan peningkatan anggaran infrastruktur yang direncanakan dalam APBN. Menurut Husaini (2013) lebih dari $60 \%$ pembangunan konstruksi di Indonesia menggunakan beton, mulai dari pembangunan yang paling sederhana hingga proyek dengan menggunakan teknologi rumit.

Perkembangan jenis konstruksi beton yang meningkat di Indonesia tentu mempengaruhi penggunaan bahan material penyusun beton yang juga akan meningkat. Berkembangnya isu keterbatasan sumber daya saat ini, maka lahirlah konsep green building dengan sustainable design, yaitu perancangan bangunan dengan menggunakan sumber daya alternatif untuk mengurangi kerusakan lingkungan. Upaya untuk mencegah kerusakan lingkungan akibat penggunaan bahan sebagai bahan dasar beton adalah dengan melakukan inovasi pembuatan beton menggunakan material limbah. Salah satu limbah yang dapat digunakan sebagai bahan pengganti penyusun beton adalah abu sekam padi dan limbah kaca.

Abu sekam padi sebagai bahan pengganti dari berat semen dapat memberikan beberapa keuntungan 


\section{Jurnal Sondir Program Studi Teknik Sipil S1, ITN MALANG}

seperti meningkatkan kekuatan pada beton. Hal ini berdasarkan penelitian Wahyu Aji Pamungkas tahun 2019, bahwa penggunaan abu sekam padi $10 \%$ sebagai pengganti semen dapat meningkatkan kuat tekan $1.48 \%$ dari beton normal menjadi 25.70 Mpa.

Sedangkan berdasarkan penelitian Nafisa tamanna (2019), limbah kaca yang dihaluskan memiliki komposisi kimia dan sifat fisik yang baik untuk bahan penyusun beton. Tekstur yang hampir sama dengan agregat halus diharapkan dapat menggantikan dan mengisi rongga kecil pada beton dan membuat beton semakin padat sehingga meningkatkan mutu kuat tekan beton (Setiawan, 2006). Hasil penelitian yang dilakukan oleh Kosim dan Arfan Hasan tahun 2014 menyimpulkan bahwa penggunaan serbuk kaca pengganti agregat halus dapat meningkatkan kuat tekan beton sebesar $11.97 \%$ terhadap kuat tekan beton normal. Selanjutnya penelitian yang dilakukan oleh Nafisa tamanna tahun 2019 menyimpulkan bahwa penggunaan campuran warna kaca (clear glass, amber glass, dan green glass) dapat meningkatkan kuat tekan $6.83 \%$ dari beton normal.

Berdasarkan uraian diatas, maka dilakukan penelitian mengenai campuran abu sekam padi $10 \%$ sebagai material substitusi semen dan limbah kaca dari campuran warna kaca (clear glass, amber glass, dan green glass) dengan variasi $0 \%, 10 \%$, $20 \%$ dan $30 \%$ sebagai bahan pengganti sebagian agregat halus. Penelitian ini bertujuan untuk mengetahui pengaruh bahan substitusi terhadap kuat tekan dan karakteristik beton yang meliputi workability, pola retak, dan lekatan agregat beton.

\section{DASAR TEORI}

Abu sekam padi

Berdasarkan penelitian Djaka suhirkam (2014), abu sekam padi disebut sebagai pozzolan alami karena kandungan senyawa silika $\left(\mathrm{SiO}_{2}\right)$ yang tinggi. Melalui reaksi reaksi antara silika $\left(\mathrm{SiO}_{2}\right)$ pada abu sekam padi dengan kalsium hidroksida $\left(\mathrm{Ca}(\mathrm{OH})_{2}\right)$ dari hasil produk hidrasi semen akan menghasilkan kalsium silikat hidrat (CSH) yang dapat meningkatkan kekuatan pada beton berdasarkan penelitian Lubis (2004).

\section{Limbah kaca}

Berdasarkan penelitian yang dilakukan oleh Setiawan (2006), Karakteristik dari penggunaan kaca sebagai agregat halus, antara lain:

- Kaca memiliki sifat tidak menyerap air sehingga diharapkan dapat mengisi rongga pada beton secara maksimal dan menyebabkan beton bersifat kedap air.

- Kaca tidak mengandung kandungan yang berbahaya.
- Kaca yang dihancurkan dapat menjadi bahan pengisi pori, sehingga diharapkan akan diperoleh beton yang lebih padat dan kekuatan beton dapat meningkat.

Dari penelitian Masturi dkk (2011), kandungan kimia kaca yang didominasi oleh kandungan silika $\left(\mathrm{SiO}_{2}\right)$, memiliki sifat unggul seperti titik lebur yang tinggi dan memiliki sifat mekanik yang sangat kuat, sehingga penggunaan kaca tersebut memiliki potensi sebagai bahan dasar komposit yang kuat.

\section{Workability beton}

Pelaksanaan pengujian slump untuk mengetahui sifat kelecakan (workability) pada campuran beton. Sifat kelecakan beton dapat dipengaruhi dari bahan utama campuran, seperti:

- Kadar air pada campuran beton.

- Terdapat bahan tambah campuran, seperti superplasticizer.

- Kadar semen dalam campuran beton.

- Bentuk butiran agregat pada campuran beton.

\section{Kuat tekan beton}

Kuat tekan beton umumnya mendefinisikan mutu dari sebuah struktur. Standar pengujian kuat tekan menggunakan ASTM C39-04a dan SNI 03-68052002. Cara menentukan nilai kuat tekan adalah sebagai berikut.

$$
f c^{\prime}=\frac{P}{A}
$$

Dimana:

fc': Kuat tekan beton (MPa)

$\mathrm{P}$ : Beban tekan $(\mathrm{N})$

A : Luas penampang benda uji $\left(\mathrm{mm}^{2}\right)$

\section{Pola retak}

Pengamatan visual terhadap pola retak pada benda uji beton dilakukan untuk mengetahui alur terjadinya retak akibat beban yang bekerja sehingga dapat diketahui indikasi terjadinya kegagalan pada beton. Berdasarkan ASTM C39/C39M-05, pola retak dibedakan menjadi 5 jenis pola retak, yaitu sebagai berikut:

- Pola retak kerucut (cone).

- Pola retak kerucut dan pecah (cone and split).

- Pola retak kerucut dan geser (cone and shear).

- Pola retak geser (shear).

- Pola retak columnar.

Berdasarkan penelitian Prayogo (2007), pola retak tersebut dapat terjadi dalam satu campuran. Hal ini dapat dipengaruhi oleh faktor berikut:

- Distribusi kekuatan antar agregat tidak merata.

- Material penyusun beton dalam pembuatan benda uji terjadi pemisahan. Hal ini dapat dipengaruhi oleh keahlian dalam pembuatan beton. 


\section{Lekatan agregat}

Menurut Habudin (2008), lekatan antara agregat dengan pasta semen sangat berpengaruh terhadap kekuatan beton. Lekatan tersebut tergantung pada kekasaran permukaan butir agregat, kadar lumpur pada agregat, zat kimia yang terdapat dalam campuran, dan pasta semen. Indikasi yang menunjukkan baik atau tidaknya lekatan adalah kondisi akhir keruntuhan partikel agregat pada campuran beton. Dalam uji ini akan dilihat bagaimana lekatan terhadap beton normal dengan beton menggunakan bahan pengganti abu sekam padi dan limbah kaca pada umur 28 hari.

\section{METODE PENELITIAN}

\section{Bentuk penelitian}

Penelitian yang dilakukan menggunakan metode eksperimen, yaitu melakukan suatu percobaan dengan membuat benda uji. Adapun proporsi benda uji ditunjukkan dalam Tabel 1 berikut ini.

Tabel 1. Proporsi Benda Uji

\begin{tabular}{|c|c|c|c|c|c|}
\hline $\begin{array}{c}\text { Pengujian } \\
\text { (Hari) }\end{array}$ & Normal & $\begin{array}{c}\text { ASP } \\
\mathbf{( 1 0 \% )} \\
+\end{array}$ & $\begin{array}{c}\text { ASP } \\
\mathbf{( 1 0 \% )} \\
\mathbf{L K}\end{array}$ & $\begin{array}{c}\text { ASP } \\
\mathbf{( 1 0 \% )} \\
+\end{array}$ & $\begin{array}{c}\text { ASP } \\
\mathbf{( 1 0 \% )} \\
+\end{array}$ \\
\hline 7 & 3 & 3 & 3 & 3 & 3 \\
\hline 14 & 3 & 3 & 3 & 3 & 3 \\
\hline 28 & 3 & 3 & 3 & 3 & 3 \\
\hline $\mathbf{( 1 0 \% )}$ & $\mathbf{2 0 \% )}$ & $\mathbf{( 3 0 \% )}$ \\
\hline Total & \multicolumn{5}{|l}{} \\
\hline
\end{tabular}

\section{Persiapan bahan beton}

Prosedur awal yang dilakukan dalam penelitian yaitu, persiapan seluruh bahan dasar material seperti semen, air, agregat halus, dan agregat kasar. Sedangkan dalam persiapan bahan substitusi beton adalah sebagai berikut:

1. Abu sekam padi

Abu sekam padi yang digunakan berasal dari kota Surabaya, Jawa timur yang telah mengalami proses pembakaran sebesar 500$700^{\circ} \mathrm{C}$. Hal ini dilakukan berdasarkan rekomendasi hasil-hasil penelitian sebelumnya.

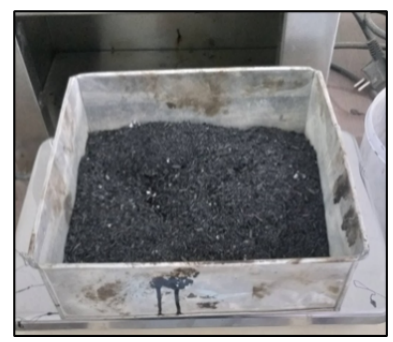

Gambar 1. Abu Sekam Padi

\section{Serbuk kaca}

Kaca yang digunakan adalah hasil dari campuran warna (clear glass, amber glass, dan green glass) botol kaca bekas yang diperoleh dari pengepul barang bekas. Adapun pembuatan serbuk kaca adalah sebagai berikut:

- Kaca terlebih dahulu dicuci agar bersih dari sisa kotoran isi botol tersebut.

- Kaca dipecahkan dengan mesin crusher hingga menjadi serbuk.

- Kaca yang sudah hancur, kemudian diayak menggunakan saringan ukuran $4.75 \mathrm{~mm}$.

- Kaca yang lolos ukuran $4.75 \mathrm{~mm}$ inilah yang digunakan sebagai pengganti agregat halus

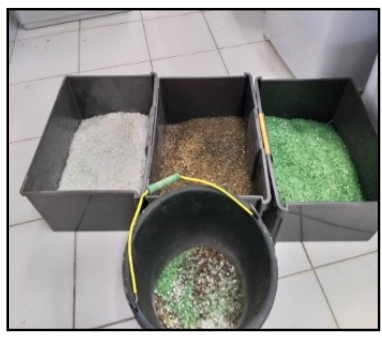

Gambar 2. Serbuk kaca

\section{Pengujian material}

Pada tahap ini dilakukan pengujian material untuk mengetahui karakteristik dari masing-masing material yang akan digunakan. Pengujian material yang dilakukan hanya fokus pada pengujian material alam. Sedangkan untuk limbah kaca dilakukan analisis saringan agregat halus dan abu sekam padi hanya dilakukan treatment penjemuran dibawah sinar matahari untuk mengurangi kelembapan dalam abu sekam padi tersebut.

\section{Pembuatan mix design}

Menurut Hayu (2017), tahap ini dilakukan untuk mengetahui proporsi campuran beton dengan mutu yang ditentukan diawal pembuatan mix design. Perencanaan campuran yang dilakukan berdasarkan ACI Committee 211. Kuat tekan rencana pada beton normal adalah campur beton dengan kuat $f c^{\prime} 25$ Mpa.

\section{Pengujian beton}

Pada penelitian ini dilakukan pengujian yang terbagi atas dua kondisi beton, yaitu saat pembuatan beton segar dan saat beton keras. Pada pembuatan beton segar dilakukan pengujian slump. Selanjutnya pada pengujian beton keras dilakukan uji kuat tekan beton berikut dengan pendokumentasian terhadap kondisi akhir masingmasing benda uji untuk keperluan analisis pola retak dan lekatan agregat pada umur 28 hari. 


\section{HASIL DAN PEMBAHASAN}

\section{Hasil pengujian slump}

Adapun hasil pengujian slump disajikan dalam Tabel 2 berikut.

Tabel 2. Hasil Uji Slump

\begin{tabular}{|c|c|c|}
\hline \multirow{2}{*}{$\begin{array}{c}\text { No. } \\
\text { Sampel }\end{array}$} & Beton & Nilai Slump \\
\cline { 2 - 3 } & (LK + ASP) & Rata-Rata (cm) \\
\hline S-A & Beton Normal & 5 \\
\hline S-B & Beton $(0+10)$ & 4.1 \\
\hline S-C & Beton $(10+10)$ & 5.5 \\
\hline S-D & Beton $(20+10)$ & 7 \\
\hline S-E & Beton $(30+10)$ & 8.3 \\
\hline
\end{tabular}

Pada penggunaan abu sekam padi tanpa serbuk kaca memiliki nilai slump dibawah beton normal. Hal ini disebabkan abu sekam padi memiliki kemampuan penyerapan air yang tinggi. Penurunan nilai slump yang terjadi juga ditunjukkan oleh beberapa peneliti sebelumnya, salah satunya Lubis (2004) bahwa jumlah air yang digunakan pada campuran beton tidak sepenuhnya digunakan untuk reaksi adukan beton, namun ada sebagian yang diserap oleh abu sekam padi.

Selanjutnya, penggunaan serbuk kaca dengan abu sekam padi meningkatkan nilai slump seiring dengan bertambahnya jumlah serbuk kaca yang digunakan. Hal ini disebabkan sifat serbuk kaca yang tidak menyerap air, sehingga air yang tidak diserap oleh serbuk kaca mempengaruhi kelecakan dari campuran beton tersebut. Abu sekam padi yang terkandung pada campuran beton tidak dapat mengimbangi jumlah air yang tidak diserap oleh serbuk kaca pengganti agregat halus. Akibatnya semakin tinggi persentase serbuk kaca maka nilai slump akan semakin meningkat.

\section{Hasil pengujian kuat tekan}

Hasil yang telah dilakukan terhadap kuat tekan beton dapat dilihat pada gambar sebagai berikut.

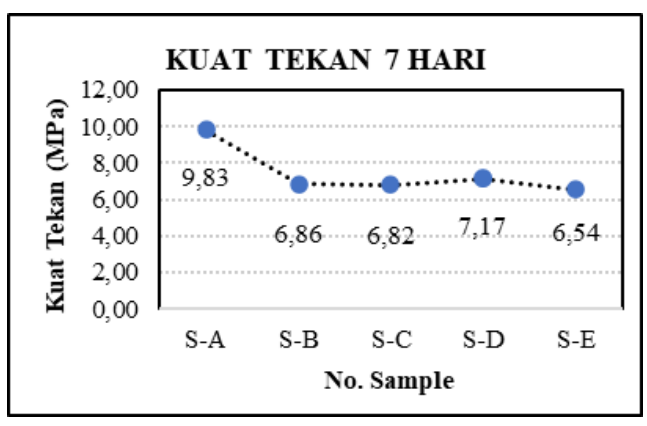

Gambar 1. Grafik Hasil Uji Kuat Tekan 7 Hari

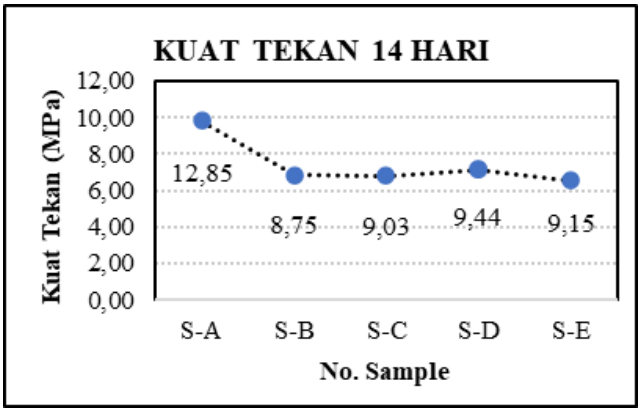

Gambar 2. Grafik Hasil Uji Kuat Tekan 14 Hari

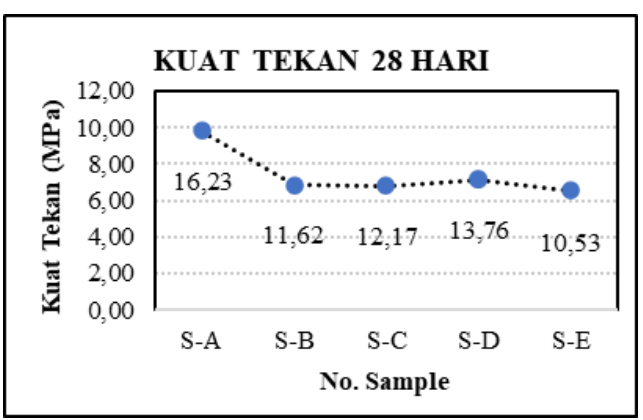

Gambar 3. Grafik Hasil Uji Kuat Tekan 28 Hari

Berdasarkan hasil uji kuat tekan dengan menggunakan abu sekam padi dan serbuk kaca memberikan pengaruh terhadap kuat tekan beton. Hasil kuat tekan akibat pengaruh penambahan abu sekam padi sebagai pengganti $10 \%$ dari berat semen menurunkan kuat tekan beton dari beton normal.

Pada beton normal (S-A) menghasilkan kuat tekan rata-rata sebesar 16.23 $\mathrm{MPa}$ sedangkan untuk beton dengan menggunakan abu sekam padi $10 \%$ (S-B) dari berat semen menghasilkan kuat tekan rata-rata sebesar $11.62 \mathrm{MPa}$ pada umur 28 hari. Hal ini menunjukkan penurunan kuat tekan sebesar $28.40 \%$. Dapat disimpulkan penggunaan abu sekam padi cenderung menurunkan kuat tekan beton. Hal tersebut disebabkan karena penggunaan abu sekam padi yang memiliki ukuran lebih besar dibandingkan dengan ukuran semen pada umumnya dimana menurut Salam (2007), ukuran semen pada umumnya yaitu sebesar 0.5-100 mikron. Sehingga penggunaan abu sekam padi cenderung akan menyelimuti butir-butir agregat dan mengurangi ikatan antara agregat dalam adukan beton. Hal ini juga didukung oleh penelitian Lubis (2004), bahwa penggunaan abu sekam padi dengan lolos ayakan mesh No. $200(0.075 \mathrm{~mm})$ dapat mengisi ruangruang kosong antar butiran serta dapat meningkatkan daya lekat antar agregat. Kekurangan lekatan yang terjadi menjadi penyebab utama 
terjadinya penurunan kuat tekan dengan campuran bahan pengganti lainnya yaitu serbuk kaca.

Penggunaan abu sekam padi $10 \%$ dan serbuk kaca dengan persentase $10 \%$ dan $20 \%$ menghasilkan kuat tekan $12.17 \mathrm{MPa}$ dan $13.76 \mathrm{Mpa}$, dimana nilai tersebut naik $4.7 \%$ dan $18.4 \%$ dari penggunaan abu sekam padi tanpa serbuk kaca. Sedangkan penggunaan abu sekam padi $10 \%$ dan serbuk kaca $30 \%$ menghasilkan kuat tekan $10.53 \mathrm{MPa}$, dimana nilai tersebut turun $9.3 \%$ dari penggunaan abu sekam padi tanpa serbuk kaca. Nilai kuat tekan yang dihasilkan dari semua variasi serbuk kaca masih dibawah beton normal. Hal ini disebabkan oleh adanya ketidaksempurnaan ikatan pada campuran beton dengan menggunakan abu sekam padi seperti yang telah dijelaskan sebelumnya.

Pada penggunaan abu sekam padi $10 \%$ dengan serbuk kaca $20 \%$ dapat menghasilkan nilai kuat tekan optimum dibandingkan dengan variasi serbuk kaca lainnya karena jumlah serbuk kaca yang ditambahkan tepat mengisi pori-pori pada beton saat beton mengeras. Sifat serbuk kaca yang mempunyai ukuran partikel lebih halus dari agregat halus alami ini dapat digunakan sebagai filler sehingga mengurangi pori-pori beton dan meningkatkan kepadatan pada campuran beton. Hal ini sesuai dengan penelitian yang dilakukan oleh Setiawan (2006) bahwa pengaruh terbesar dari penggunaan serbuk kaca adalah sebagai pengisi pori atau filler.

\section{Hasil pengujian pola retak}

Dari pengujian kuat tekan beton yang dilakukan, dapat dilihat juga beberapa jenis pola retak kehancuran dan lekatan agregat dari benda uji. Pola retak yang terjadi pada umur 28 hari dapat dilihat pada Tabel 3 berikut.

Tabel 3. Hasil Uji Pola Retak

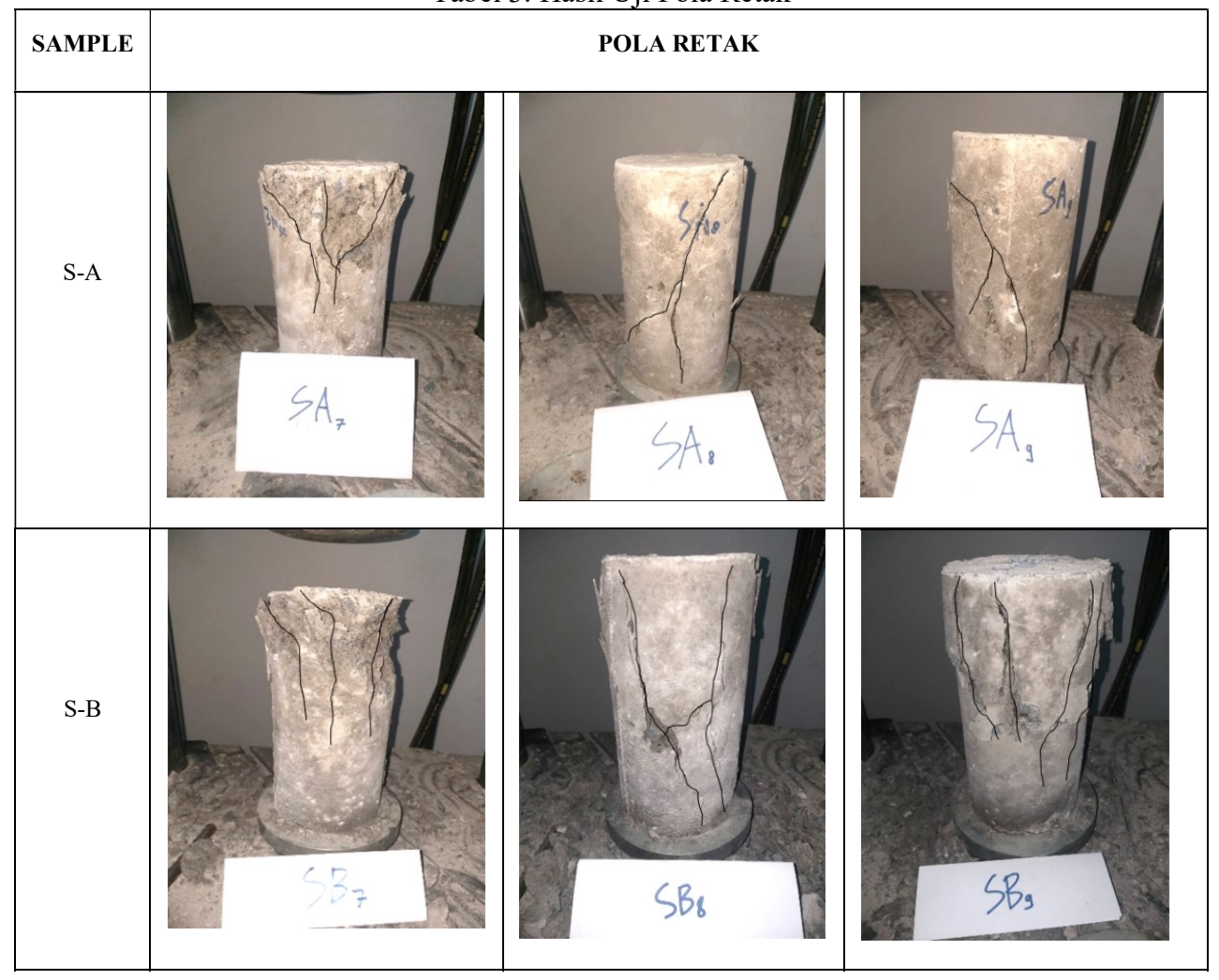




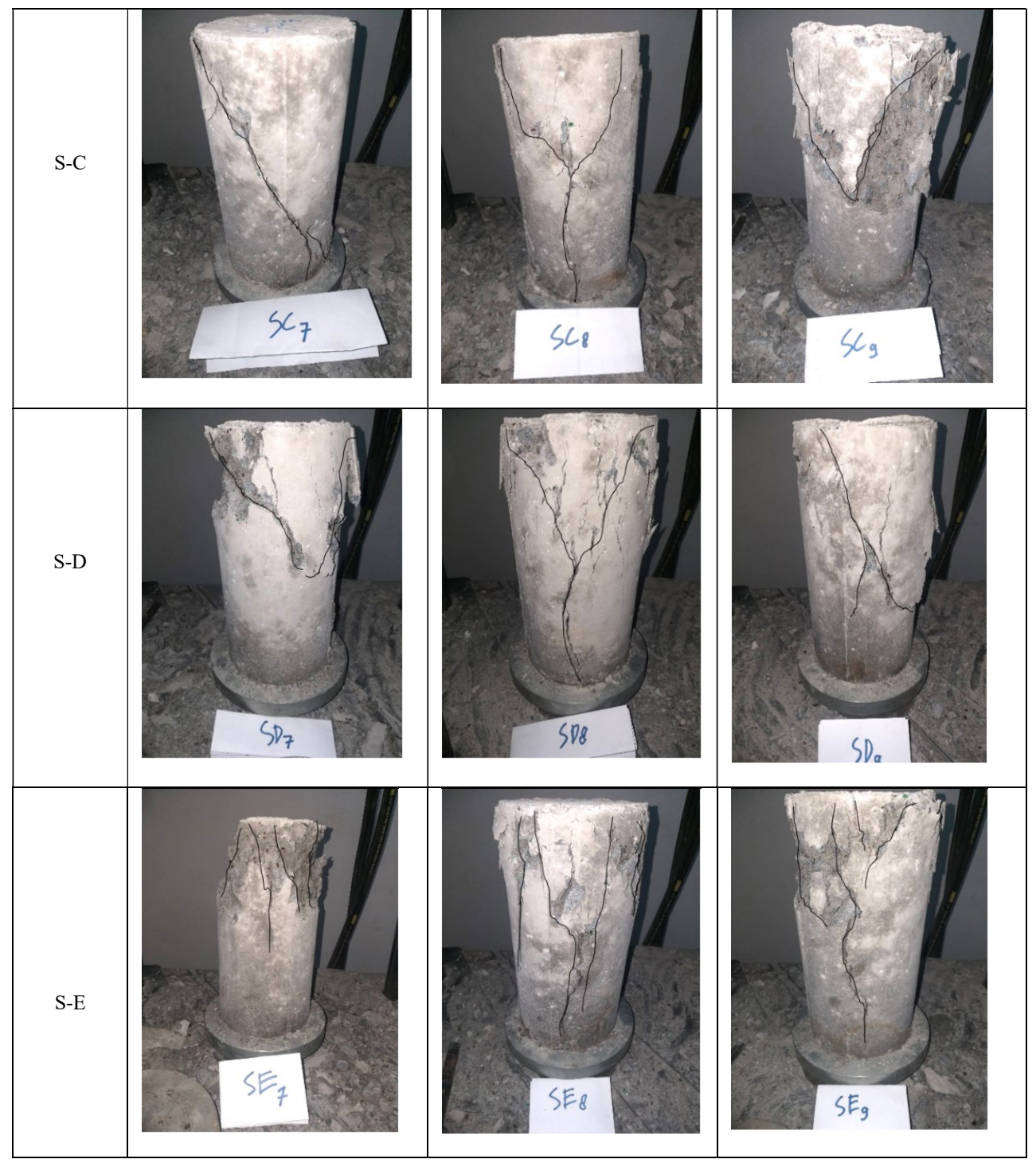

Berdasarkan hasil pengamatan visual setelah dibandingkan dengan syarat pola retak ASTM C39/C39M-05, pola retak yang terjadi pada benda uji S-A (beton normal) secara umum memiliki pola retak cone and shear failure. Hal ini dilihat dari retakan pertama yang terjadi dari sisi atas silinder, kemudian membentuk garis diagonal dan retakan cenderung berpusat di tengah silinder. Pola retak akibat gaya geser ini terjadi karena benda uji beton tidak benar-benar tertahan pada sisi atas dan sisi bawahnya. Namun terdapat sisi yang dapat bergeser, dalam hal ini adalah sisi atas yang menerima tegangan lebih besar. Sehingga ketika terjadi pembebanan dari bawah dan atas silinder, beban tidak bertemu dan menyebabkan beban menjadi berpusat pada satu sisi ditengah silinder. Hal inilah yang dapat mengurangi nilai kuat tekan beton sebenarnya.
Pola retak yang terjadi pada benda uji S-B (beton dengan menggunakan abu sekam padi 10\%) tergolong dalam pola columnar, karena benda uji mengalami pola retak yang tegak lurus atau vertikal dari ujung dan cenderung memusat pada tengah silinder. Hal ini disebabkan beban yang terjadi pada permukaan bagian bawah dan bagian atas silinder tidak merata, dan tegangan cenderung terpusat pada tengah silinder. Hal ini mengindikasikan permukaan beton yang tidak rata dan terdapat kelamahan pada isi beton sehingga tidak dapat menahan gaya yang terjadi.

Pada pola retak benda uji S-C dan S-D tergolong pada pola retak cone and shear failure. Pola retak yang terjadi memiliki kesamaan dengan pola retak pada benda uji S-A. Hanya saja memiliki retakan yang menyebabkan beberapa partikel beton terlepas setelah pembebanan. Sedangkan pola retak pada benda uji S-E tergolong pada pola retak columnar, 
karena retak yang terjadi tegak lurus dari gaya beban yang terjadi. Pola retak yang terjadi memiliki kesamaan dengan pola retak S-B, namun pada lokasi pola retak yang terjadi terdapat lebih banyak partikel-partikel beton yang lepas dari benda uji lainnya.

Perbandingan pola retak beton normal terhadap beton dengan menggunakan bahan substitusi terlihat bahwa penggunaan bahan substitusi pada beton membuat pola retak yang dihasilkan berubah drastis. Penggunaan abu sekam padi dan serbuk kaca yang ditambahkan menyebabkan pola retak beton semakin lesbrittle dibandingkan dengan beton tanpa bahan substitusi dimana pola retak yang terjadi bersifat getas yang ditandai dengan pecahnya sisi permukaan beton.

\section{Hasil pengujian lekatan agregat}

Dari pengamatan visual yang dilakukan pada lekatan agregat beton umur 28 hari dapat dilihat pada Tabel 4 berikut.

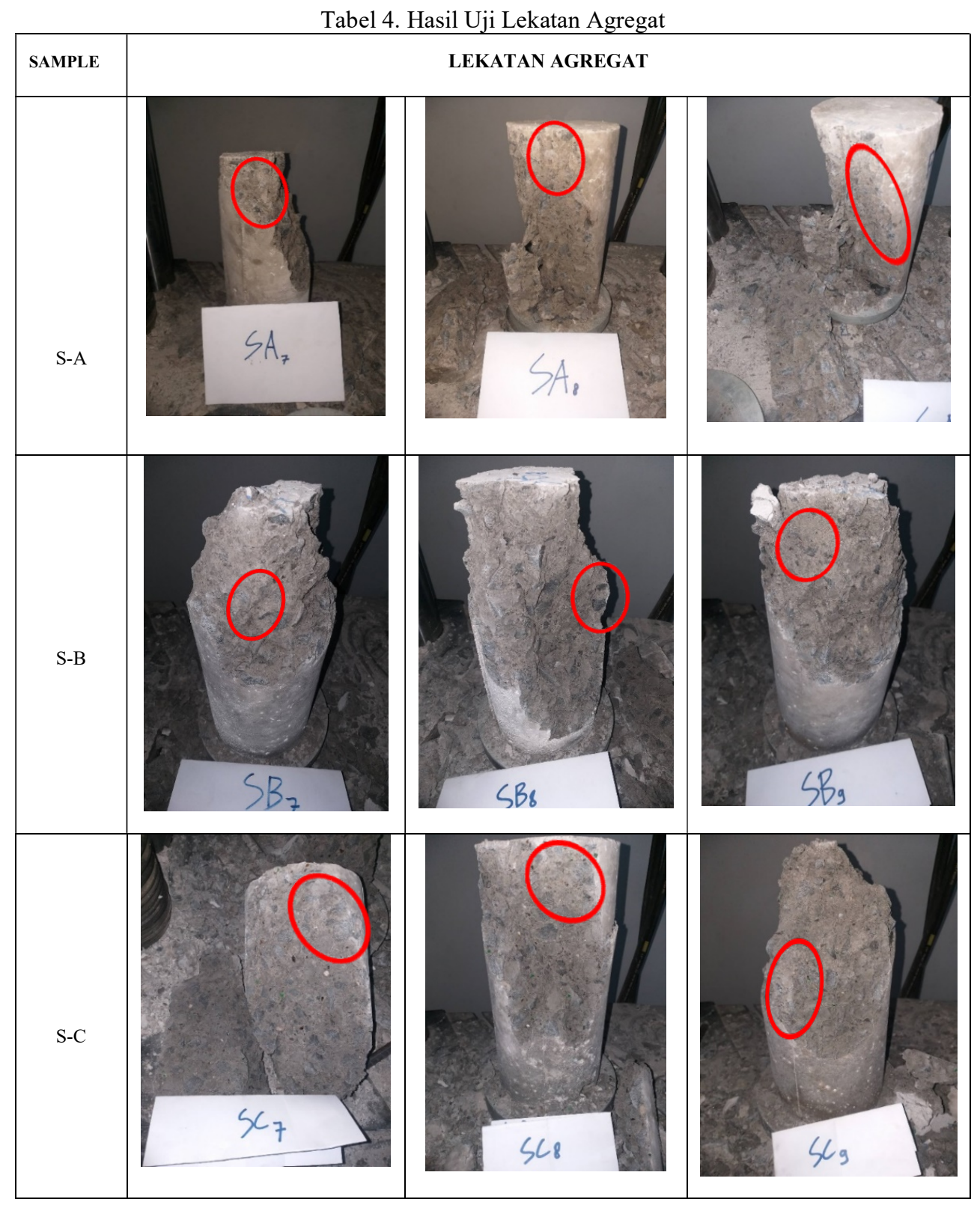




\section{Jurnal Sondir Program Studi Teknik Sipil S1, ITN MALANG}

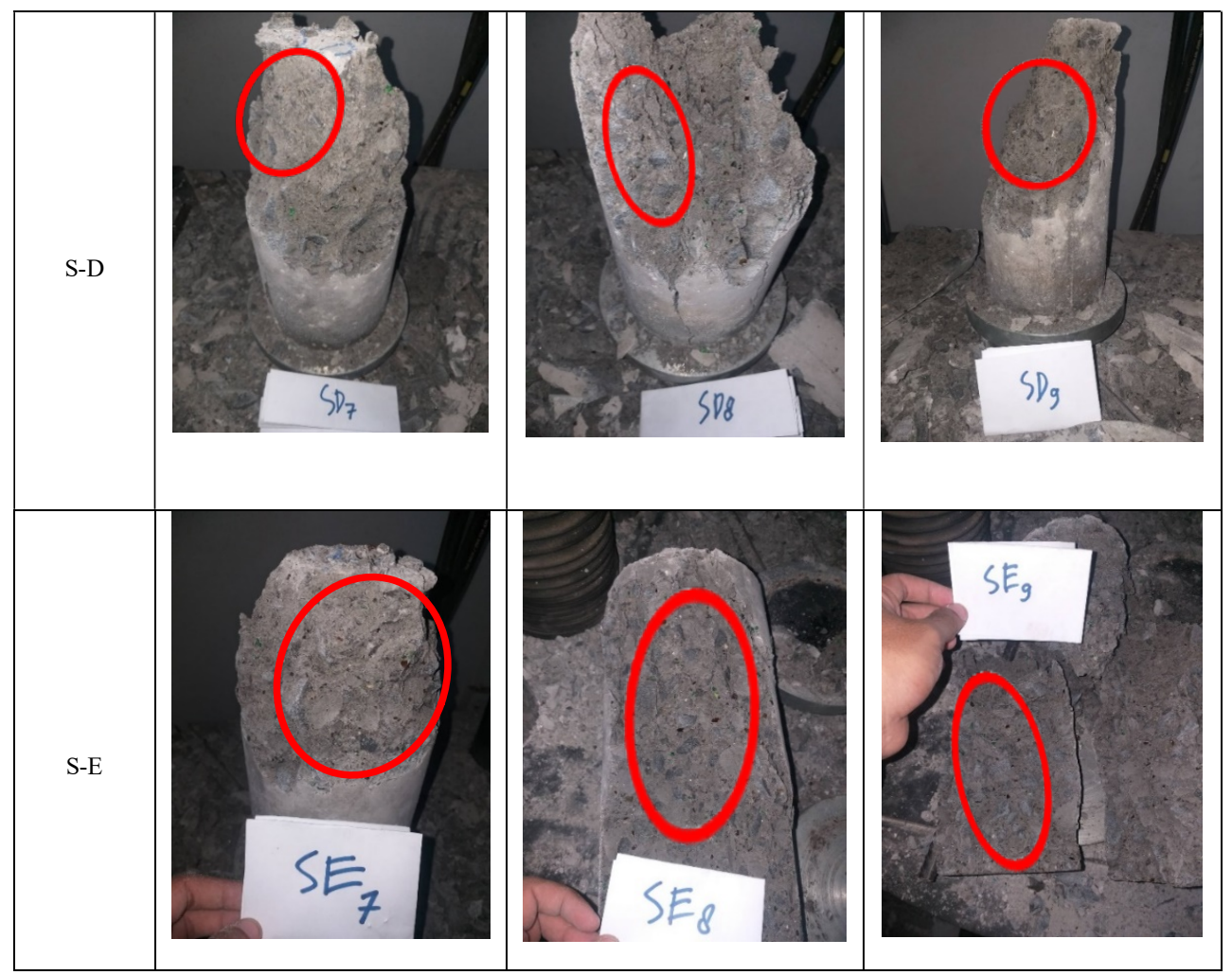

Pada hari ke-28 dari hasil kuat tekan beton, penggunaan abu sekam padi dan serbuk kaca ini cenderung mengurangi nilai kuat tekan beton. Melalui pengamatan visual terhadap lekatan agregat, pada benda uji S-A dimana tanpa menggunakan bahan substitusi abu sekam padi dan serbuk kaca, terlihat keruntuhan belahan yang terjadi melewati ikatan antara agregat, namun masih terlihat beberapa keruntuhan belahan yang terjadi pada agregat.

Pada benda uji S-B dimana menggunakan abu sekam padi $10 \%$ tanpa serbuk kaca, terlihat keruntuhan belahan terjadi pada ikatan antara agregat dan terdapat coakan akibat lepasnya agregat kasar pada campuran beton. Pada benda uji S-C dan S-D dengan menggunakan serbuk kaca $10 \%$ dan $20 \%$ dengan abu sekam padi $10 \%$, terlihat keruntuhan belahan juga terjadi pada ikatan antara agregat namun masih terdapat beberapa bagian yang mengalami keruntuhan melewati agregat. Pada benda uji S-E dimana menggunakan sebuk kaca $30 \%$ dan abu sekam padi $10 \%$, terlihat keruntuhan belahan yang terjadi tidak melewati agregat sehingga lebih banyak terjadi pada ikatan antara agregat.

Dari indikasi pendukung hasil pengamatan visual terhadap lekatan agregat, keruntuhan beton normal dan beton campuran bahan substitusi cenderung terjadi pada ikatan antara agregat. Hal ini terlihat dari belahan keruntuhan yang tidak melewati agregat dari beton, namun melewati ikatan antara agregatnya.

Seperti yang telah dibahas sebelumnya, kondisi abu sekam padi yang digunakan menyebabkan adanya partikel yang tidak terpakai dalam campuran beton. Partikel yang bukan merupakan bahan pengikat inilah yang turut menyebabkan ikatan antar agregat menjadi berkurang sebab hal tersebut mengganggu proses pengikatan antara semen dengan agregat kasar maupun agregat halus dengan campuran serbuk kaca.

\section{PENUTUP \\ Kesimpulan}

Berdasarkan data dan analisis dari hasil pengujian di laboratorium, dapat ditarik kesimpulan sebagai berikut:

1. Penggunaan abu sekam padi $10 \%$ sebagai pengganti sebagian semen dan variasi penggunaan serbuk kaca $(0 \%, 10 \%, 20 \%$, dan $30 \%$ ) terhadap pengaruh kuat tekan beton cenderung menurunkan nilai kuat tekan beton dari pada beton normal.

2. Penggunaan serbuk kaca yang dapat menjadikannya sebagai filler pada campuran beton untuk mengisi kekosongan pori-pori pada beton dengan kadar variasi serbuk kaca tertentu dapat meningkatkan dan menurunkan nilai kuat 


\section{Jurnal Sondir Program Studi Teknik Sipil S1, ITN MALANG}

tekan beton dibandingkan dengan beton campuran abu sekam padi tanpa serbuk kaca. Namun nilai kuat tekan yang dihasilkan masih dibawah nilai kuat tekan beton normal.

3. Penggunaan abu sekam padi $10 \%$ dapat menurunkan nilai slump sehingga kemudahan dalam pembuatan beton segar berkurang. Hal ini disebabkan dari sifat abu sekam padi yang memiliki tingkat penyerapan air yang cukup tinggi.

4. Pada penggunaan serbuk kaca dapat meningkatkan nilai slump pada beton. Semakin tinggi kadar serbuk kaca yang digunakan, maka nilai slump yang diperoleh semakin besar. Hal ini disebabkan karena kaca memiliki bentuk yang licin serta sifat kaca yang tidak menyerap air, sehingga air yang tidak diserap oleh serbuk kaca meningkatkan workability campuran beton.

5. Pengamatan visual terhadap pola retak beton dengan penggunaan abu sekam padi dan serbuk kaca membuat pola retak berubah drastis dari beton normal. Semakin tinggi kadar serbuk kaca yang diberikan dengan menggunakan abu sekam padi membuat pola retak beton semakin berkurang sifat getas (brittle) pada beton dan terlihat lebih rapuh dibandingkan dengan beton tanpa bahan substitusi (beton normal), dimana beton normal pada pola keruntuhan bersifat getas yang ditandai dengan pecahnya benda uji.

6. Pengamatan visual terhadap lekatan agregat terhadap pengaruh penggunaan abu sekam padi $10 \%$ dan variasi serbuk kaca cenderung terjadi pada ikatan antar agregat, sedangkan pada agregat kasar tidak mengalami kerusakan atau keruntuhan. Hal ini disebabkan daya ikatan antar agregat yang kurang baik akibat penggunaan abu sekam padi yang cenderung menyelimuti agregat sehingga mengganggu proses ikatan antar agregat.

7. Penggunaan abu sekam padi $10 \%$ dan serbuk kaca 20\% menghasilkan kuat tekan optimum dibandingkan dengan beton campuran substitusi lainnya. Kuat tekan optimum yang dihasilkan sebesar 13.76 Mpa, namun lebih kecil dari beton normal yaitu $16.23 \mathrm{MPa}$ atau terjadi penurunan $15.21 \%$ dari beton normal. Sedangkan kuat tekan minimum dihasilkan pada kadar abu sekam padi $10 \%$ dan serbuk kaca $30 \%$ dengan menghasilkan kuat tekan sebesar $10.53 \mathrm{MPa}$ atau menurun $35 \%$ dari beton normal.

\section{Saran}

Berdasarkan hasil analisis dan kesimpulan, maka dapat disarankan sebagai berikut:
1. Melakukan suatu treatment dalam proses penggunaan abu sekam padi sebagai bahan pengganti semen. Hal ini dapat dilakukan dengan menyaring abu sekam padi dengan ayakan mesh No. $200(0.075 \mathrm{~mm})$ sehingga dapat mengisi pori-pori pada campuran beton serta meminimalisir butiran abu sekam padi yang tidak digunakan pada campuran beton.

2. Perlu dilakukan kontrol yang ketat terhadap penggunaan bahan substitusi abu sekam padi dan serbuk kaca yang digunakan. Hal yang dapat dilakukan adalah kontrol terhadap suhu pembakaran sekam padi yang akan digunakan, pengujian terhadap kadar air pada abu sekam padi, serta pengujian massa jenis serbuk kaca yang digunakan. Sehingga analisis hasil penelitian lebih akurat.

3. Perlu dilakukan proses dokumentasi yang lebih baik terhadap pengamatan visual terhadap pola retak dan lekatan agregat agar menghasilkan data yang dapat dianalisis lebih akurat.

4. Memperhatikan terhadap material dasar penyusun beton untuk menjaga kualitas agar sesuai dengan standar yang disyaratkan pada bahan campuran beton.

5. Perlu adanya kajian lebih lanjut mengenai abu sekam padi sebagai bahan pengganti semen dan serbuk kaca sebagai bahan pengganti agregat halus terhadap kuat tekan beton.

\section{DAFTAR PUSTAKA}

ACI Committee 211. Standard Practice for Selecting Proportions for Normal, Heavywight, And Mass Concrete. American Concrete Institute.

ASTM C39/C39M. Standard Test Method for Compressive Strength of Cylindrical Concrete Specimens.

Djaka suhirkam, D. (2014). Beton Mutu K-400 Dengan Penambahan Abu Sekam Padi Dan Superplastisizer. Palembang.

Hayu,G.A ， Siswanto.R, Suyoso.H. (2017). Pengaruh Penggunaan Pasir Pantai Sebagai Agregat Halus dan Cangkang Kerang sebagai Substitusi Parsial Semen terhadap Kuat Tekan Beton. Jurnal Rekayasa Sipil Dan Lingkungan, 194.

Husaini, H. W. (2013). Peranan Beton Dalam Pembangunan Infrastruktur Indonesia. Jakarta: Pu-net.

Loly Siti Khadijah, L. (2004). Pengaruh Penggunaan Abu Sekam Padi Sebagai Material Pengganti Semen Terhadap Kuat Tekan Dan Kuat Tarik Beton . Depok 
Murti, F. R. (2016). Pengaruh Penambahan Serat Bendrat, Abu Sekam Padi dan Bestmittel Terhadap Kuat Tekan, Kuat Tarik Belah dan Modulus Elastisitas.

Nafisa tamanna, R. t. (2019). Construction and Building Material. Performance of recycled waste glass sand as partial replacement of sand in concrete.

Nurhayat Degirmencia, A. Y. (2011). Utilization of waste glass as sand replacement in cement mortar.

Setiawan. (2006). Pengaruh Penggunaan Agregat Kaca Pada Beton Ditinjau Dari Segi Kekuatan Dan Shrinkage.

SNI 03-6805-2002. Metode Pengujian Untuk Mengukur Nilai Kuat Tekan Beton Pada Umur Awal Dan Memproyeksikan Kekuatan Pada Umur Berikutnya.

Wahyu Aji, P. (2019). Efekvitas penggunaan abu sekam padi sebagai pengganti sebagian semen dalam pembuatan beton. Surabaya 